Article

\title{
Sustainable Innovation Governance: An Analysis of Regional Innovation with a Super Efficiency Slack-Based Measure Model
}

\author{
Kai Xu ${ }^{1}$ D, Lawrence Loh $^{2, *}$ and Qiang Chen ${ }^{1}$ \\ 1 School of Economics and Management, Tongji University, Shanghai 200092, China \\ 2 Centre for Governance, Institutions and Organisations, NUS Business School, National University of \\ Singapore, 1 Business Link, Singapore 117592, Singapore \\ * Correspondence: bizlohyk@nus.edu.sg
}

Received: 11 February 2020; Accepted: 2 April 2020; Published: 9 April 2020

check for updates

\begin{abstract}
As China is undergoing economic transformation and facing increasing energy and environmental problems, it is essential to pay special attention to sustainable innovation governance. This research took industrial waste and total energy consumption into consideration and uses a super efficiency slack-based measure (SBM) model to empirically evaluate the regional innovation efficiency of Chinese provinces. The results showed that the efficiency of China's regional sustainable innovation has not changed significantly over recent years. In addition, the results also showed large and varying degrees of innovation efficiency across different provinces. Eastern China, in comparison to central and western China, showed higher innovation efficiency. In addition, we found a slightly increasing trend in terms of innovation efficiency disparities between the three areas. On the basis of these findings, the reasons for the innovation efficiency gap between different regions were analyzed. The impacts of influential factors on sustainable innovation efficiency were further explored. We found that technology market maturity affected sustainable innovation efficiency positively, while government funding had a negative impact on sustainable innovation efficiency. Industrial structure and environmental regulations had no significant effect on sustainable innovation efficiency. Finally, some implications for improving governance performance in terms of sustainable innovation were provided.
\end{abstract}

Keywords: sustainable innovation governance; regional innovation; super efficiency slack-based measure model

\section{Introduction}

Technological innovation, in contemporary times, has had a significant impact on economic and productivity growth, and has become the core driver of regional sustainable development and economic growth [1,2]. Technological innovation enables a country to achieve economic efficiency in terms of knowledge spillover, human capital accumulation, research and development (R\&D) activities, and the international proliferation of technology. After the global financial crisis, sustainable innovation was key for companies to gain a competitive advantage and for countries to maintain sustainable development. Due to the critical impact of technological innovation on economic growth, the Chinese government attaches great importance to innovation and also sees it as a national policy. However, unbalanced development across regions causes differences in innovation efficiency, energy efficiency, and emissions efficiency. In addition, the efficiency of regional innovation differs greatly between Chinese regions $[3,4]$. The uneven development of regional innovation in China causes imbalances in regional economic development [5]. One region may enhance its innovation efficiency by improving technological development and technological commercialization [6]. Meanwhile, technological innovation may 
impact negatively on energy conservation and environmental emissions reductions because of the rebound effects caused by efficiency improvements [7]. Moreover, technological innovation processes often produce industrial waste and carbon dioxide during the transformation period $[8,9]$. Such undesirable outputs in the innovation process are difficult to dispose of. In addition, these massive emissions of industrial waste and carbon dioxide create new challenges for traditional technological innovation. Businesses and governments should incorporate economic, social, and environmental sustainability dimensions into their decision-making processes to improve sustainable governance. The challenge of sustainable development has drawn the attention of academics and policymakers. It is widely believed that sustainable technological innovations may be the key to addressing this dilemma, and may include effective ways to balance profitability and environmental responsibility while pursuing sustainable development. To alleviate global climate change, this requires the development and adoption of sustainable technological innovations. Sustainable technological innovations can improve energy utilization efficiency, reduce pollution, and produce ecological improvements. In terms of technology, economic development, and environmental pollution, improving sustainable innovation efficiency is of theoretical and practical significance.

Research on the efficiency of regional innovation governance has attracted growing attention in recent decades [10]. Researchers have attached importance to the social, technical, economic, political, and environmental issues of sustainability [11-14]. Rapid development, particularly in cities, has brought growing energy consumption and pollution emissions to China [15], which is not sustainable $[16,17]$. Corporate sustainability functions can be analyzed through studying related governance characteristics [18-20]. Corporate governance with codified guidance can lead to sustainable value creation [21-23]. In addition, some scholars have studied the relationship between sustainable performance and innovation efficiency [24-27]. However, to date, very little research has been conducted on sustainable innovation efficiency and undesirable outputs [28]. Discussions on the effects of undesirable outputs on innovation efficiency have been lacking. Meanwhile, no research has analyzed the factors influencing sustainable innovation efficiency from a quantitative perspective. Thus far, the factors that affect sustainable innovation efficiency remain unclear. Our study aimed to address this topic with a super efficiency slack-based measure (SBM) model and a regression model. We took industrial waste and total energy consumption into consideration and extended sustainable innovation governance to include undesirable outputs. This research comprehensively compared the regional innovation efficiency of Chinese regions and further analyzed regional innovation efficiency from a macro level. In addition, this research introduced a super efficiency SBM model into the research on innovation efficiency for the first time. We also analyzed the factors that influence sustainable innovation governance. Moreover, this paper can provide meaningful information on innovation governance, energy conservation, and emissions reduction policies.

The rest of this paper is organized as follows: Section 2 reviews the literature on sustainable innovation governance. Section 3 introduces the research methodology, the super efficiency SBM model, and the regression model (for empirical analysis). Section 4 displays the evaluation results and the factors influencing sustainable innovation efficiency. Section 5 discusses the research results and compares them to relevant research results. Contributions to theory and practice, limitations, and further research are also discussed. Section 6 draws conclusions and includes policy recommendations.

\section{Literature Review}

\subsection{Sustainable Innovation Governance}

According to Cooke [29-31], a regional innovation system is a regional organization system that consists of production enterprises and research institutions, which are divided but associated with each other and which generate and support innovation. Industrial enterprises play a major role in R\&D inputs, patent applications, and transformative achievements, and are the main providers of technological innovation. Traditionally, innovation mainly refers to new product development, 
process and service innovation, and economic growth [32]. Sustainable innovation expands these concepts to broader social, institutional, ethical, and ecological dimensions [33]. As a concept in environment-related innovations, sustainable innovation includes new technologies, products, services, or business models that have positive impacts on the environment and society [1,34], bridges corporate social responsibility and innovation, and plays a crucial role in China's rapid economic growth. Meanwhile, sustainable innovation stresses the environmental effect during innovation processes, including the environmental wastes and warm gas emissions [35-37]. It emphasizes not only economic benefits but also environmental outputs that improve sustainability performance and contribute to solving environmental problems [38]. With increasing concerns about industrial wastes and global warming, the undesirable outputs have to be taken into account in innovation governance [27,39]. To solve the problems of energy consumption and environmental pollution, the academic community has conducted extensive research on the relationship between environmental protection and economic growth [9].

Given the worldwide attention to sustainable innovation, it is necessary to consider how to balance the relationship of innovation governance with pollution mitigation and energy conservation [40]. After four decades of economic reforms and opening to the world, China has experienced a high economic growth stage at an average annual rate of $9.26 \%$ since 1978 , which is higher than that of the U.S. or Japan. However, this rapid economic growth comes at a huge expense of resource depletion and environmental degradation. If anything, the problems with energy security and environmental pollution are getting worse. The total energy consumption in China is rising, while the shortage of natural resources has gradually become a huge problem that restricts the sustainable development of the Chinese economy. Unlike developed countries that use clean energy extensively, economic development in China is still driven largely by fossil fuels, even today. The coal-based energy structure in China generates a high level of environmental pollutants. This poses a huge challenge to the sustainable development of the Chinese economy, which faces the crossroads of change. Industrial pollutions and $\mathrm{CO}_{2}$ emissions negatively impacted the sustainable growth of China [6]. As economic development enters the new normal stage, the economic growth rate of China decreases to medium from high speed. This means that China urgently needs economic transformation and industrial upgrading to sustain its economic growth. For long-term sustainable development, China has to find innovative solutions to realize sustainability performance.

China has been devoted to energy savings and emissions reduction to achieve sustainable economic growth. The technological innovation of new energy companies is strongly supported by the government. China has also adopted a series of laws and regulations on environmental and resource management. In the Five-Year Plans, technological innovation, market-oriented reform, industrial structure adjustment, and regional balance development have been adopted for sustainable economic growth [41]. International cooperation mechanisms are developed to promote the achievement of sustainable development goals. In line with the Paris Climate Agreement in 2016, China's $\mathrm{CO}_{2}$ emissions would peak around 2030, and carbon emissions intensity would reduce by $60-65 \%$ compared to the 2005 levels. To achieve this goal, the Chinese central government has put significant efforts into the design and improvement of low-carbon governance to deal with climate change [42]. Due to the limited innovation resources and harsh environmental regulations in China, it is necessary to enhance regional innovation capability by using as few innovation inputs as possible to get more innovation outputs while reducing the undesirable outputs. In the long run, improving the efficiency of regional sustainable innovation provides an effective way to overcome the natural resource constraints faced by current economic development. However, due to the difficulties in implementing policies and the information asymmetry between the local and the central governments, many policies have not been well expressed at the provincial level. Sustainable innovation governance in China faces many difficulties, and the governance effect may not be obvious in the short term. At the same time, China's regional economic development is unbalanced. Regional industrial enterprises have different performances in the process of innovation input-output transformation. China is at the beginning of 
its sustainable governance with regard to lowering its innovation processes' undesirable outputs, but it is still difficult to judge the effectiveness of sustainable governance in the short term. Therefore, the following hypothesis was formulated.

Hypothesis 1 (H1). Sustainable innovation efficiencies in Chinese provinces do not vary in recent years.

\subsection{Research on Innovation Efficiency}

Farrell [43] defined the efficiency measurement method of multi-input and multi-output, which could be divided into technical efficiency and allocative efficiency. Technical efficiency reflects the ability to reduce inputs under established conditions of outputs, or to increase outputs under established conditions of inputs. Allocative efficiency reflects the ability to invest optimally at a given technology and factor prices. Since it is difficult to obtain the prices of innovation inputs, it is difficult to calculate the allocation efficiency of innovation resources. The innovation efficiency in this paper mainly refers to the technical innovation efficiency. Innovation is the whole process of new products from the conception, research, and development to commercial applications. Previous research had found a strong correlation between innovation inputs and outputs [44,45]. Innovation efficiency focuses on innovation performance mainly concerning the output efficiency of innovation inputs [46]. The regional innovation process is also an input-output process which is represented by a regional technical system with input-output functions.

In the recent two decades, researchers all over the world have already evaluated innovation efficiency at length at both the regional and country levels. Lee and Park [47] compared the R\&D efficiency of Asian countries through data envelopment analysis (DEA). Sharma and Thomas [48] evaluated the R\&D efficiency of 22 developed and developing countries with the DEA model. Guan and Chen [49] measured the regional R\&D efficiency in China using a non-radial DEA model. Karadayi and Ekinci [50] evaluated the R\&D performance of EU countries using categorical DEA models and examined the relationship between R\&D performance and political-regulatory-economic situation of the countries. Wang et al. [51] evaluated the industrial eco-efficiency of Fujian province in China with an SBM-DEA model. He et al. [52] analyzed the impact of government competition on regional R\&D efficiency through the DEA model. Dai et al. [53] studied the spatial evolution of technological innovation efficiency and talents' sticky wages. Chen et al. [54] proposed a dynamic analytical framework on R\&D efficiency considering the dynamic interdependence between regional R\&D activities over different periods. Anderson and Stejskal [55] evaluated the diffusion efficiency of innovation through the DEA model, and found the different innovation performances among EU member states. Belgin [56] analyzed the regional R\&D efficiency of 12 Turkish regions and effective variables. Cao et al. [57] studied the effect of market competition on innovation efficiency in China's high-tech industries. We can see that the regional differences in innovation efficiency are widespread, not only in China, but also in other countries. In view of the huge imbalance in economic development, governance capabilities, scientific and technological resources investments, and sustainable development policies among Chinese regions, we proposed the following hypothesis.

Hypothesis 2 (H2). There exist obvious differences in innovation efficiency among regions in China.

The efficiency of sustainable innovation is affected by many factors. Previous research has found that government funding (GOV) [58-61], technology market maturity (TEC) [3,62-64], industrial structure (IND) [65-67], and environmental regulations (ER) [68-70] could affect sustainable innovation efficiency (IE). Enterprises are facing high risk in R\&D innovation, and need very large R\&D funds. It is difficult to meet the demand only by the company's own funds. The local government's R\&D funding could reduce the $R \& D$ expenditures of enterprises and help increase the enthusiasm for R\&D activities. This may help companies to increase the innovation efficiency. We used the ratio of government R\&D funding in total R\&D expenditure to characterize the impact of government funding. Technology 
market maturity reflects the commercialization level of innovation outputs. A developed technology market is conducive to constructing a good innovation atmosphere, which is very helpful to promote the innovation outputs of enterprises. We used the ratio of technology market turnover to regional gross domestic product (GDP) as the technology market maturity variable. Industrial structure is closely linked to innovation. The emerging strategic industries in the secondary industry, such as high-end equipment manufacturing, new materials, and new energy industries, have high technology, economic benefits, and low pollution and have become the important pillar industry in regional development. The secondary industry is believed to help improve the regional capacity for sustainable innovation. We used the ratio of the secondary industry's outputs to regional GDP to represent industrial structure. Environmental regulation has an important impact on sustainable innovation. At present, China's environmental pollution problem is getting more serious. The government has formulated relevant policies to regulate enterprises' economic activities, and urged them to reduce pollution emissions and energy consumption to achieve sustainable governance. At the same time, external pressures on environmental regulation have prompted companies to upgrade their technological innovation capabilities and improve the efficiency of sustainable innovation. We used the ratio of completed investment in the treatment of industrial pollution to regional GDP to represent environmental regulations. This led to the following hypotheses.

Hypothesis 3a (H3a). Government funding has a positive impact on sustainable innovation efficiency.

Hypothesis $3 \mathbf{b}(\mathbf{H} 3 \mathbf{b})$. Technology market maturity positively impacts sustainable innovation efficiency.

Hypothesis 3c (H3c). Industrial structure has a positive impact on sustainable innovation efficiency.

Hypothesis 3d (H3d). Environmental regulations positively impact sustainable innovation efficiency.

Existing research in relation to innovation efficiency mainly measures the innovation efficiency and influence factors, neglecting the important aspect of sustainability performance of regional innovation, and lacking empirical research on sustainable innovation efficiency. In the new era of achieving sustainable development in China, it is particularly important to carry out sustainable innovation governance and evaluate its innovation efficiency.

\section{Methods}

\subsection{Super Efficiency DEA-SBM Model}

There are mainly parametric and nonparametric methods in efficiency evaluation. Compared with the parametric methods, nonparametric methods do not need to establish a functional relationship between the explanatory variables and the dependent variables in advance, which avoids the errors of subjectivity in parameter setting. As the representative of the nonparametric methods, the DEA method can deal with multi-output analysis, and is the most frequently used method in efficiency research on energy, environment, ecology, and technological innovation [71,72]. The DEA provides an ordinal ranking of relative efficiency within a set of comparable decision-making units (DMUs), and identifies the best practices leading to the identification of an efficient frontier. In addition, in the DEA model, the weights of inputs and outputs do not need to be set in advance.

Data envelopment analysis method was first put forward by Charnes et al. [73] to determine the relative efficiency and productivity of the DMUs by comparing multiple inputs and multiple outputs. All the traditional DEA models, including the CCR (Charnes, Cooper, and Rhodes) model and the BCC (Banker, Charnes, and Cooper) model, are either input-oriented or output-oriented, without considering input and output slacks. Undesirable outputs are inevitably produced along with desirable outputs, which have a negative impact on the efficiency of decision-making units [74]. Several methods are used to deal with slacks in undesirable outputs. Some research treated undesirable outputs as inputs 
indicators. Scheel [75] proposed the reciprocal transformation method which transforms the value of undesirable outputs into desirable outputs. Seiford and Zhu [76] converted all negative undesired outputs into positive values through a transformation vector. Färe and Grosskopf [77] proposed an approach by distinguishing between weak and strong disposability to treat the undesirable outputs. All these methods are radial and oriented, and do not consider the slacks of inputs and outputs, which are contrary to the real production process. In ranking and comparing DMUs, each input or output factor must be adjusted proportionally to efficient targets.

The efficiency value of traditional DEA models is between 0 and 1. If the DMUs are of the same efficiency value 1 , the relative quality cannot be compared further. In order to overcome the shortcomings of the traditional models, Tone [78] proposed a super efficiency slack-based measure model, which solved the slack problems of inputs and outputs by directly putting the slack variables into the objective function. The super efficiency SBM model could perfectly deal with undesirable outputs, and further compare the effective DMUs. The super efficiency SBM model has been widely used in research on energy efficiency and environmental efficiency [79].

This research used a super efficiency SBM model for efficiency evaluation. The super efficiency SBM model with undesirable outputs can be expressed as follows. The vectors $s^{-}, s^{g}$, and $s^{b}$ refer to slack variables of input, desirable output, and undesirable output, respectively. $\lambda$ is the weight vector.

$$
\begin{aligned}
& \min \theta^{*}=\frac{\frac{1}{m} \sum_{i=1}^{m}\left(\bar{x} / x_{i 0}\right)}{1+\frac{1}{s_{1}+s_{2}}\left(\sum_{r=1}^{s_{1}}\left(s_{r}^{g} / y_{r 0}^{g}\right)+\sum_{r=1}^{s_{2}}\left(s_{r}^{b} / y_{r 0}^{b}\right)\right)} \\
& \text { s.t. }\left\{\begin{array}{l}
\bar{x} \geq X \lambda \\
\overline{y^{g}} \leq Y^{g} \lambda \\
\overline{y^{b}} \geq Y^{b} \lambda \\
\bar{x} \geq x_{0}, \overline{y^{g}} \leq y_{0}, \overline{y^{b}} \geq y_{0}^{b}, \lambda>0
\end{array}\right.
\end{aligned}
$$

\subsection{Indicators Selection and Data Sources}

In mainland China, there are 31 provincial administrative regions overall, including 22 provinces, 5 autonomous regions, and 4 province-level municipalities. Tibet is excluded in our research due to the lack of data availability. Our data contained 30 provinces in eastern, central and western areas. The eastern area comprises 11 provinces: Beijing, Tianjin, Shanghai, Liaoning, Hebei, Shandong, Jiangsu, Zhejiang, Fujian, Guangdong, and Hainan, most of which are in the coastal regions with developed economies. The central area is China's traditional agricultural base, consisting of 10 provinces: Heilongjiang, Jilin, Inner Mongolia, Henan, Shanxi, Anhui, Hubei, Hunan, Jiangxi, and Guangxi. The western area is the most underdeveloped area, consisting of nine provinces: Chongqing, Sichuan, Shaanxi, Yunnan, Gansu, Xinjiang, Guizhou, Qinghai, and Ningxia.

The technological innovation process mainly encompasses the R\&D process and the achievements transformation process, including the production process. In recent years, Chinese industrial enterprises have rapidly increased R\&D expenditures. The various indicators were used based on literature analysis and data availability. In terms of input indicators, labor and capital were used. The R\&D personnel full-time equivalent, $R \& D$ expenditure, and new product development project [80-82] were used to represent the input indicators. The R\&D personnel full-time equivalent is the sum of the workload of R\&D full-time personnel and the workload of part-time personnel converted according to actual working hours. R\&D expenditure represents the annual actual expenditures for internal R\&D activities. New product development project is the annual number of new product development projects. For the selection of output indicators, invention applications and new product sale revenue $[58,64]$ were used to represent the desirable outputs. Invention applications is the number of invention applications per 
year. New product sales revenue is the annual sales revenue from new products. Industrial pollutants were the main undesirable outputs, including effluent, the exhaust gas, and solid waste. We chose annual industrial $\mathrm{SO}_{2}$ emissions to represent the industrial pollutants [83]. Meanwhile, with the rising concern of global warming, carbon emission abatement is of major national importance $[84,85]$. As the largest contributor of $\mathrm{CO}_{2}$ emissions in the world, China plays an important role in controlling global $\mathrm{CO}_{2}$ emissions [86]. We chose annual $\mathrm{CO}_{2}$ emissions as another undesirable output.

However, there are no official statistics on the regional $\mathrm{CO}_{2}$ emissions in China. Hence, this study estimates the $\mathrm{CO}_{2}$ emissions based on energy consumption and carbon emission coefficients [87]. Considering the data availability of our indicators, we focused our research on the latest two years of 2015 and 2016, which could reflect the current status of China's regional sustainable innovation efficiency. Since we set the time lag from inputs to outputs as one year, we used inputs data in 2015 and 2016 and outputs data in 2016 and 2017. All data were from China Statistical Yearbook, China Statistical Yearbook on Environment, and China Energy Statistical Yearbook.

\subsection{Regression Model}

In our study, we use the super efficiency SBM model with undesirable outputs to calculate the sustainable innovation efficiency of China's provinces and areas. Ordinary least squares (OLS) regression and Tobit regression model are the most frequently used models in the research of influence factors of innovation efficiency [88]. Even under mild assumptions about the scores, OLS will provide the best, unbiased linear estimates for the independent variables [89]. In the empirical context of multiple independent variables, the OLS estimator has high reliability if no serious multicollinearity observed. In line with relevant research [90-93], we used the OLS regression model to analyze relevant variables' influence on sustainable innovation efficiency. According to the existing research and data availability, this paper tested the impacts of government funding, technology market maturity, industrial structure, and environmental regulations on sustainable innovation efficiency. Considering influence factors' variables and the OLS regression model, the final form of the analysis model of the factors affecting innovation efficiency is:

$$
\mathrm{IE}_{\mathrm{it}}=\beta_{0}+\beta_{1} \mathrm{GOV}+\beta_{2} \mathrm{TEC}+\beta_{3} \mathrm{IND}+\beta_{4} \mathrm{ER}+\varepsilon_{\mathrm{it}}
$$

In this formula, the subscripts $i$ and $t$ mean the $i$ th province's innovation efficiency in the $t$ th year. $\beta_{0}, \beta_{1}, \beta_{2}, \beta_{3}, \beta_{4}$ are the unknown coefficients, and $\varepsilon_{\mathrm{it}}$ is the random error. "IE" is innovation efficiency. "GOV" "TEC" "IND" "ER" represent the government funding, technology market maturity, industrial structure, environmental regulations. Data on influencing factors' variables are all obtained from China Statistical Yearbook, China Statistical Yearbook on Science and Technology, and China Statistical Yearbook on Environment. Table 1 presents the definitions and sources of the variables.

Table 1. Definitions and sources of the variables.

\begin{tabular}{|c|c|c|c|}
\hline Variable Name & $\begin{array}{l}\text { Variable } \\
\text { Symbol }\end{array}$ & Explanation & Data Sources \\
\hline Government funding & GOV & $\begin{array}{l}\text { The share of government funding } \\
\text { in intramural R\&D expenditure of } \\
\text { industrial enterprises }\end{array}$ & $\begin{array}{c}\text { China Statistical } \\
\text { Yearbook on Science and } \\
\text { Technology }\end{array}$ \\
\hline $\begin{array}{c}\text { Technology market } \\
\text { maturity }\end{array}$ & TEC & $\begin{array}{l}\text { The ratio of technology market } \\
\text { turnover to regional GDP (gross } \\
\text { domestic product) }\end{array}$ & $\begin{array}{c}\text { China Statistical } \\
\text { Yearbook }\end{array}$ \\
\hline Industrial structure & IND & $\begin{array}{l}\text { The ratio of secondary industry's } \\
\text { outputs to regional GDP }\end{array}$ & $\begin{array}{l}\text { China Statistical } \\
\text { Yearbook }\end{array}$ \\
\hline $\begin{array}{l}\text { Environmental } \\
\text { regulations }\end{array}$ & ER & $\begin{array}{l}\text { The ratio of completed investment } \\
\text { in treatment of industrial } \\
\text { pollution to regional GDP }\end{array}$ & $\begin{array}{l}\text { China Statistical } \\
\text { Yearbook on } \\
\text { Environment }\end{array}$ \\
\hline
\end{tabular}




\section{Empirical Results}

\subsection{Efficiency Evaluation Results}

The descriptive statistics for the data of all the variables in China are shown in Table 2. From Table 2, the medians of different indicators are smaller than the mean values. The large standard deviation shows an unbalanced status of indicators. The maximum is more than 30 times the minimum for undesirable outputs.

Table 2. Descriptive statistics of input and output variables.

\begin{tabular}{|c|c|c|c|c|c|c|c|c|}
\hline $\begin{array}{l}\text { Inputs and } \\
\text { Outputs }\end{array}$ & Variable & Unit & Year & Mean & Median & Std. dev. & Min & Max \\
\hline \multirow[t]{3}{*}{ Inputs } & $\begin{array}{c}\text { Research and } \\
\text { development } \\
\text { (R\&D) personnel } \\
\text { full-time } \\
\text { equivalent }\end{array}$ & man-year & 2015 & $87,941.567$ & $47,113.000$ & $114,658.077$ & 1285.000 & $441,304.000$ \\
\hline & & & 2016 & $3,606,677.419$ & $2,370,531.630$ & $4,528,636.543$ & $77,055.318$ & $16,572,478.303$ \\
\hline & $\begin{array}{c}\text { New product } \\
\text { development } \\
\text { projects }\end{array}$ & item & 2015 & $10,875.667$ & 5948.000 & $15,242.423$ & 121.000 & $57,204.000$ \\
\hline \multirow{2}{*}{$\begin{array}{l}\text { Desirable } \\
\text { outputs }\end{array}$} & & & 2016 & $13,061.600$ & 8001.500 & $18,761.858$ & 126.000 & $66,843.000$ \\
\hline & & & 2016 & $61,104,658.339$ & $36,141,288.993$ & $81,672,698.842$ & $982,837.842$ & $333,624,190.504$ \\
\hline \multirow[t]{4}{*}{$\begin{array}{l}\text { Undesirable } \\
\text { outputs }\end{array}$} & $\mathrm{SO}_{2}$ emissions & $\begin{array}{c}10,000 \\
\text { tons }\end{array}$ & 2015 & 36.744 & 30.315 & 24.646 & 1.700 & 113.450 \\
\hline & & & 2016 & 29.169 & 25.610 & 19.210 & 1.430 & 73.910 \\
\hline & $\mathrm{CO}_{2}$ emissions & $\begin{array}{c}10,000 \\
\text { tons }\end{array}$ & 2015 & $41,983.906$ & $33,290.580$ & $31,106.795$ & 4243.483 & $131,314.896$ \\
\hline & & & 2016 & $43,086.715$ & $34,832.106$ & $32,158.029$ & 3435.557 & $126,571.486$ \\
\hline
\end{tabular}

The super efficiency method distinguishes the effective DMUs. Based on our evaluation using the super efficiency SBM model with undesirable outputs, the innovation efficiency of China's 30 provinces is shown in Table 3. Figure 1 shows the efficiency level distribution of China's regions in 2015 and 2016. From Table 3, we can see that the innovation efficiency value could be more than 1 .

Table 3. Innovation efficiency of 30 regions.

\begin{tabular}{cccccc}
\hline DMU & $\mathbf{2 0 1 5}$ & $\mathbf{2 0 1 6}$ & DMU & $\mathbf{2 0 1 5}$ & $\mathbf{2 0 1 6}$ \\
\hline Beijing & 2.007 & 2.460 & Anhui & 1.149 & 1.096 \\
Tianjin & 0.827 & 0.629 & Jiangxi & 0.782 & 0.882 \\
Hebei & 0.516 & 0.566 & Henan & 0.572 & 0.676 \\
Liaoning & 0.613 & 0.619 & Hubei & 0.761 & 0.783 \\
Shanghai & 1.057 & 1.273 & Hunan & 1.110 & 1.131 \\
Jiangsu & 0.779 & 0.707 & Guangxi & 1.015 & 1.023 \\
Zhejiang & 1.060 & 1.017 & Chongqing & 1.045 & 1.020 \\
Fujian & 0.643 & 0.653 & Sichuan & 0.679 & 0.704 \\
Shandong & 0.624 & 0.669 & Guizhou & 0.634 & 0.595 \\
Guangdong & 1.261 & 1.320 & Yunnan & 0.570 & 0.559 \\
Hainan & 1.000 & 1.000 & Shaanxi & 0.493 & 0.569 \\
Shanxi & 0.536 & 0.593 & Gansu & 0.466 & 0.516 \\
Inner Mongolia & 0.591 & 0.638 & Qinghai & 1.000 & 1.000 \\
Jilin & 1.053 & 1.059 & Ningxia & 0.632 & 0.667 \\
Heilongjiang & 0.443 & 0.487 & Xinjiang & 0.617 & 0.591 \\
\hline
\end{tabular}




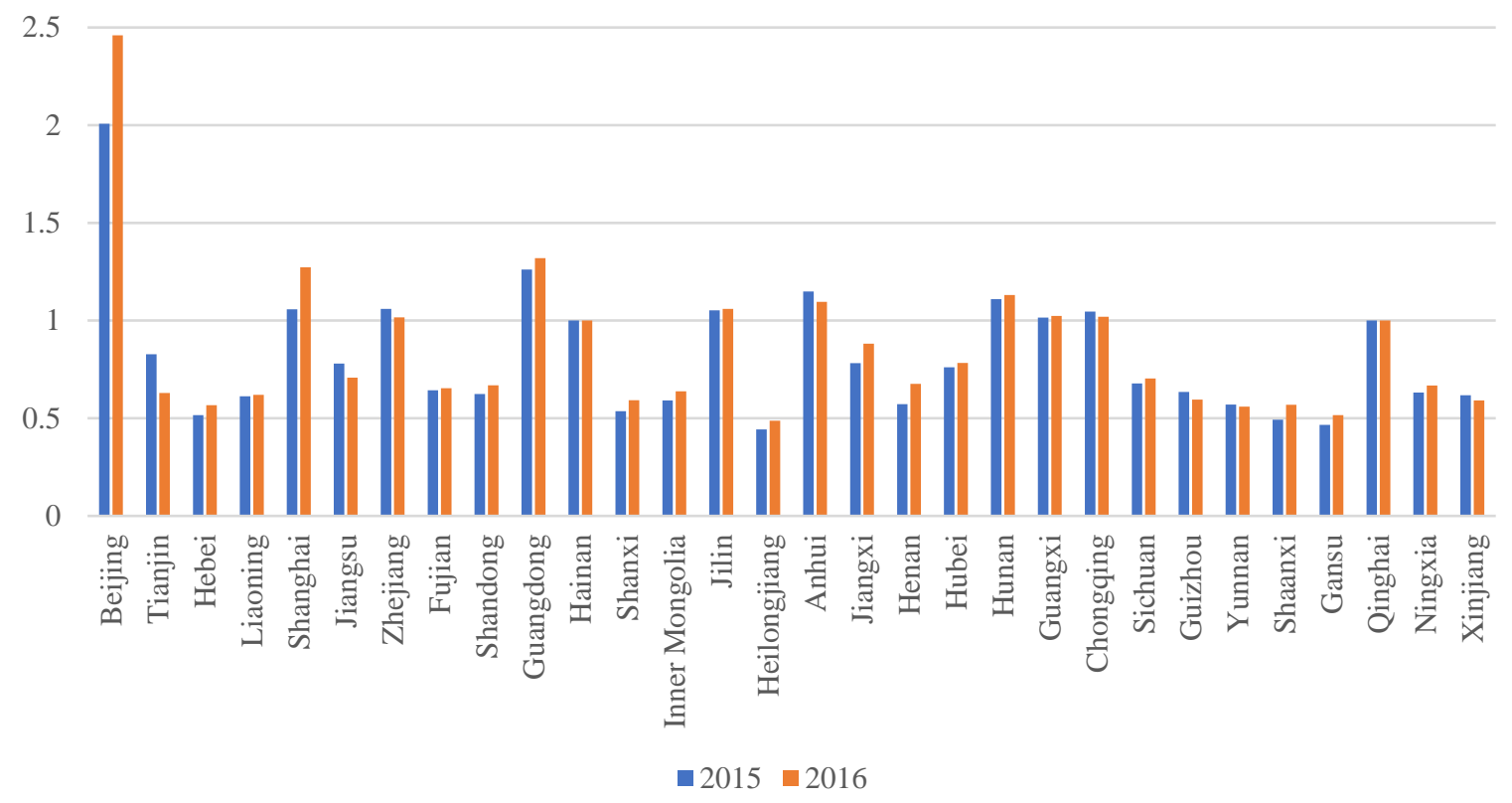

Figure 1. Innovation efficiency of the 30 provinces in 2015 and 2016.

\subsection{Analysis of Innovation Efficiency Changes}

The regional innovation efficiencies in 2015 and 2016 were compared. Seen from Table 3 and Figure 1, it is obvious that in these two years the innovation efficiency values were more than 1 in nine provinces, including Beijing, Guangdong, Anhui, Hunan, Zhejiang, Shanghai, Jilin, Chongqing, and Guangxi. Most of the nine provinces are located in eastern and central China. The average values of innovation efficiency for the remaining provinces were 0.656 and 0.672 in these two years, with a small rise. It is worth noting that among all the provinces with low efficiency values, Heilongjiang had the lowest efficiency values, which were lower than 0.5 in the two years.

We used the Mann-Whitney test to compare the efficiencies in the years 2015 and 2016. The P-value is 0.745 , showing no significant efficiency changes in the two years. The probability that the efficiency in the year 2015 is higher than the efficiency in 2016 is 0.476 . From 2015 to 2016, the standard deviation values are 0.327 to 0.386 , showing the slight efficiency change between the regions. Many of the provinces have improved innovation efficiencies. Among them, Beijing and Shanghai increased most significantly, with increases in values of 0.452 and 0.215 , respectively. Eight provinces had reduced efficiencies: Yunnan, Chongqing, Xinjiang, Guizhou, Zhejiang, Anhui, Jiangsu, and Tianjin. The efficiency value of Tianjin reduced the most, with a decrease in value of 0.1979 . Beijing stayed at the highest efficiency level among provinces with efficiency values of 2.007 and 2.460 for 2015 and 2016, respectively. Heilongjiang province stayed at the lowest level with efficiency values of 0.443 in 2015 and 0.487 in 2016.

The efficiency rankings of all the 30 DMUs were obtained, as shown in Table 4. Seven provinces had reduced efficiency rankings, i.e., Anhui, Fujian, Yunnan, Zhejiang, Xinjiang, Guizhou, and Tianjin. Tianjin's ranking decreased the most, from twelfth to twenty-first. Eleven provinces rankings remained unchanged, Beijing, Guangdong, Hunan, Chongqing, Hainan, Qinghai, Jiangsu, Liaoning, Hebei, Gansu, and Heilongjiang. Twelve provinces showed progression in the efficiency rankings, including Henan, Shanghai, Shandong, Inner Mongolia, Guangxi, Hubei, Shanxi, Shaanxi, Jilin, Jiangxi, Sichuan, and Ningxia. Among them, Henan's ranking increased the most, from twenty-fourth to sixteenth. Beijing tops the efficiency rankings followed by Guangdong. Gansu and Heilongjiang are at the bottom of the list. 
Table 4. Innovation efficiency rankings of China's 30 provinces in 2015 and 2016.

\begin{tabular}{ccclcc}
\hline DMU & $\mathbf{2 0 1 5}$ & $\mathbf{2 0 1 6}$ & DMU & $\mathbf{2 0 1 5}$ & $\mathbf{2 0 1 6}$ \\
\hline Beijing & 1 & 1 & Anhui & 3 & 5 \\
Tianjin & 12 & 21 & Jiangxi & 13 & 12 \\
Hebei & 27 & 27 & Henan & 24 & 16 \\
Liaoning & 22 & 22 & Hubei & 15 & 13 \\
Shanghai & 6 & 3 & Hunan & 4 & 4 \\
Jiangsu & 14 & 14 & Guangxi & 9 & 7 \\
Zhejiang & 5 & 9 & Chongqing & 8 & 8 \\
Fujian & 17 & 19 & Sichuan & 16 & 15 \\
Shandong & 20 & 17 & Guizhou & 18 & 23 \\
Guangdong & 2 & 2 & Yunnan & 25 & 28 \\
Hainan & 10 & 10 & Shaanxi & 28 & 26 \\
Shanxi & 26 & 24 & Gansu & 29 & 29 \\
Inner Mongolia & 23 & 20 & Qinghai & 10 & 10 \\
Jilin & 7 & 6 & Ningxia & 19 & 18 \\
Heilongjiang & 30 & 30 & Xinjiang & 21 & 25 \\
\hline
\end{tabular}

\subsection{Regional Comparative Analysis}

The innovation efficiencies of China's 30 provinces in 2015 and 2016 were evaluated based on a super efficiency SBM model. In order to make a comparative analysis of regional innovation efficiency from the sub-country level, we compared innovation efficiencies in eastern, central, and western areas.

We used the Kruskal-Wallis test to compare the efficiencies in the three areas and found that the $\mathrm{P}$-value is 0.034 , which means remarkable differences exist at the $5 \%$ significance level. The significance level obtained is the precise unilateral significance level. As can be seen from Figure 2, from 2015 to 2016, the efficiency values of eastern, central, and western China increased. Correspondingly, the innovation efficiency of the whole country also increased from 0.82 to 0.85 , but there is still potential to be improved. All the above results show that there are still obvious efficiency gaps among different regions in China with an upward trend.

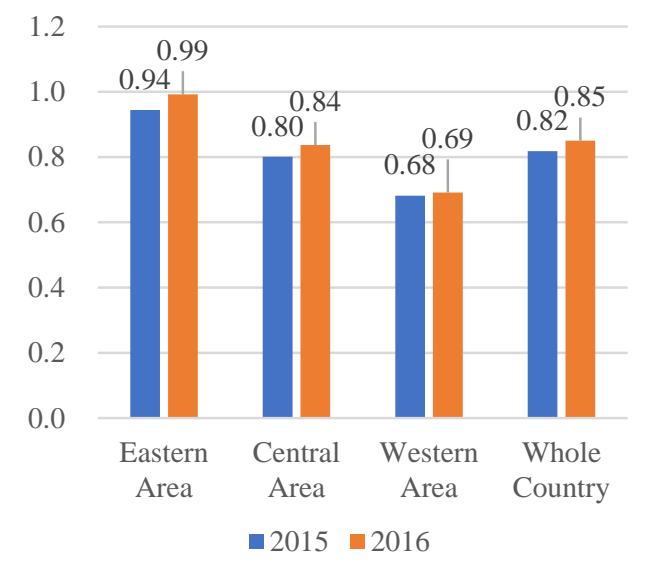

Figure 2. Regional innovation efficiency.

Innovation efficiency values in eastern and central China were always higher than in western China. In eastern China, economic development had developed rapidly with a relatively high degree of market opening for many years. Provinces in eastern China have an advantage in technological innovation, energy saving, and environmental protection policies, which could attract talent and technology. This promotes the effective utilization of innovation resources. The eastern provinces have the strong economic ability to support the R\&D innovation of sustainable technologies, and promote the development of low carbon environmental protection industries. Moreover, strict legal supervision has generally been adopted in the eastern region, which augments the effective implementation 
of environmental protection and energy conservation policies and contributes to the promotion of sustainable innovation efficiency. The central and western areas have lower levels of economic and technology development in comparison to eastern China.

We can see the apparent gaps in the above three areas. To better understand the regional gaps in innovation efficiency, we examined the figure of regional gaps, which were obtained by subtracting the low efficiency value from the high value of the two regions. For example, the efficiency gap of "eastern-western" was derived from the efficiency value of the eastern region minus the efficiency value of the western area. As seen from Figure 3, the efficiency gap of eastern-western was always higher than "central-western" and "eastern-central". In addition, the regional disparities of the three areas increased slightly.

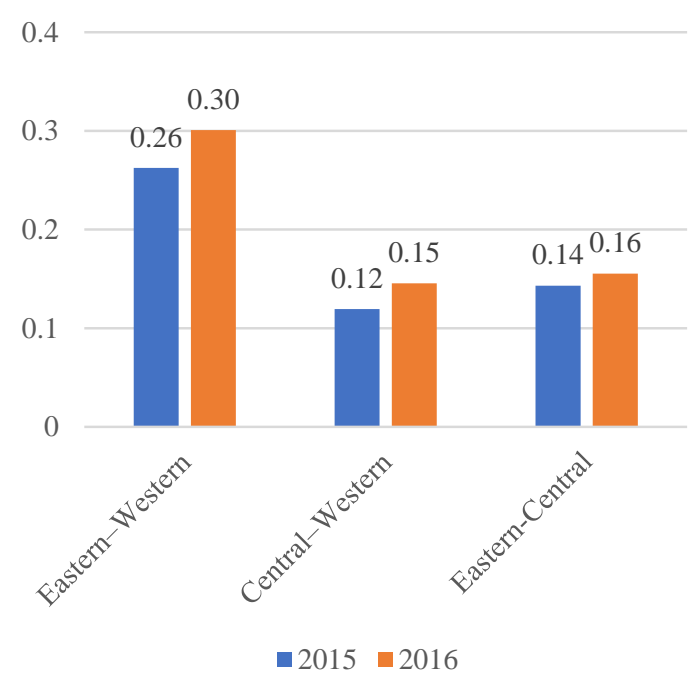

Figure 3. Regional innovation efficiency gaps.

\subsection{Influence Factors Analysis}

The impacts of our four influential factors on innovation efficiency were determined as shown in Table 5. We took the coefficient of TEC as an illustrative example. The coefficient of TEC is 0.099, which indicates that if the TEC increases or decreases by one unit, then the corresponding innovation efficiency would also increase or decrease by 0.099 units. This means that TEC has a positive impact on innovation efficiency. The variance inflation factor (VIF) values of variables are 1.670, 1.590, 1.590, and 1.010 with a mean value of 1.470 , as shown in Table 6. The VIF results indicate that there is no significant collinearity between the variables.

Table 5. Regression results.

\begin{tabular}{cccc}
\hline & Coef. & Std. Err. & $\mathbf{t}$ \\
\hline GOV & $-0.008^{*}$ & 0.003 & -2.600 \\
TEC & $0.099 * * *$ & 0.099 & 6.740 \\
IND & -0.008 & 0.005 & -1.450 \\
ER & -0.043 & 0.040 & -1.070 \\
_cons & $1.270 * * *$ & 0.268 & 4.730 \\
R-squared & 0.539 & & \\
Adj R-squared & 0.506 & & \\
Root MSE & 0.249 & & \\
F & 16.100 & & \\
Prob. $>$ F & 0.000 & & \\
\hline
\end{tabular}

Note: * The value in parentheses is $\mathrm{t}$ statistics, presenting their significance at a level of $10 \%$; ${ }^{*}$ The value in parentheses is $t$ statistics, presenting their significance at a level of $5 \%$; ${ }^{* *}$ The value in parentheses is $t$ statistics, presenting their significance at a level of $1 \%$. 
Table 6. VIF results.

\begin{tabular}{ccc}
\hline Variable & VIF & 1/VIF \\
\hline GOV & 1.670 & 0.598 \\
TEC & 1.590 & 0.628 \\
IND & 1.590 & 0.630 \\
ER & 1.010 & 0.985 \\
\hline Mean VIF & 1.470 & \\
\hline
\end{tabular}

Our results indicated that GOV has a negative impact on innovation efficiency at a significance level of $10 \%$. The reason may be that the government's excessive investment in the R\&D activities led to inefficient utilization of innovation resources. Over the past several decades, China's government has invested numerous resources in R\&D activities. This means that excessive investment in R\&D activities likely does not improve innovation efficiency. Consequently, it is essential to strengthen the management of innovation resource utilization.

The maturity of the technology market is conducive to improving the efficiency of China's sustainable innovation. TEC has a significant effect on innovation efficiency at a significance level of $1 \%$. It shows that a mature technology market can promote innovation outputs. The mature technology market is conducive to the realization of the market value of scientific and technological achievements and the promotion of innovation efficiency. With the continuous development of the technology market, the technology trading platform is getting more active, which promotes technology dissemination and development. Our results indicate that technology transfer is becoming an important way to enhance China's innovation ability.

There is no significant correlation between industrial structure and sustainable innovation efficiency. The possible reason is that China's secondary industry has a phenomenon of non-sustainable development, which makes the development of the second industry unhelpful to the improvement of sustainable innovation efficiency. Meanwhile, with the rapid development of China's economy, the industrial structure of various regions has also been continuously upgraded in recent years, while the regional development is unbalanced. Improving innovation capability and development quality is the key to industrial policies.

The impact of environmental regulation on sustainable innovation efficiency is not significant. Appropriate environmental regulation can promote technological innovation, thereby increasing business productivity and gaining competitive advantage. At the same time, increasing investment in environmental pollution control funds will crowd out innovative investment funds, reduce innovation capacity, and have a certain negative impact on sustainable innovation efficiency.

\section{Discussions}

\subsection{Hypotheses}

Three hypotheses were proposed based on the literature review. We then tested our hypotheses through the DEA model and statistical methods. From Table 3 and Figure 1 we can see that there were no obvious efficiency changes in the two years. Our Mann-Whitney test also confirmed these results. Therefore Hypothesis 1 is accepted. One reason for the finding could be due to differences in the implementation of the central government's policies in each province, resulting in varying innovation performance in the provinces. At the same time, it is difficult to achieve significant improvements in innovation efficiency in a short period of time due to the complexity of innovation activities. From Figures 2 and 3, significant differences in innovation efficiency among eastern, central, and western China are observed. The Kruskal-Wallis test confirmed these results. Hypothesis 2 is strongly supported. This is in line with previous research on China's regional innovation efficiency [53,54]. This is due to the imbalances in economic development and investment differences in innovation resources among regions. Consistent with the results of other studies, the eastern area had the highest innovation 
efficiency in the three areas. As we all know, eastern China has a relatively more developed economy, higher government governance capability, and higher innovation capacity. In addition, we found the regional disparities of the three areas increased slightly. Innovation resources were increasingly concentrated in the eastern area, exacerbating the development gap between regions. What is more, we analyzed the influencing factors of sustainable innovation efficiency from a quantitative perspective. From our regression results, technology market maturity affects sustainable innovation efficiency significantly, while government funding has a negative impact on sustainable innovation efficiency. $\mathrm{H} 3 \mathrm{a}, \mathrm{H} 3 \mathrm{c}$, and $\mathrm{H} 3 \mathrm{~d}$ are rejected while H3b is strongly supported. This is consistent with most research results $[3,52]$. Excessive government subsidies have reduced the incentive for enterprises to innovate while mature technology markets are conducive to increasing innovation outputs.

\subsection{Contribution to Theory}

This study confirmed the correlation between innovation inputs and outputs, and verified that regional innovation systems are important components of national innovation systems. Not only do regional innovation systems differ from each other in their characteristics and efficiencies, but they also differ significantly from national innovation systems. This research confirmed the influencing factors of sustainable innovation efficiency, which complements the sustainable innovation theory. In addition, this study highlighted the impact of undesirable outputs on sustainable innovation efficiency. Sustainable governance may help companies contribute to a more sustainable environment, improve competitive advantage, and enhance their business sustainability. Companies should value the importance of business sustainability in their governance and take measures to reduce undesirable outputs to improve innovation efficiency.

This empirical research also compared the regional innovation efficiency from a macro level, which is a good research perspective to explore the regional gaps. In addition, this research applied the super efficiency SBM model in innovation efficiency research. No other studies have used this model in innovation efficiency. The super efficiency SBM model can deal with undesirable outputs effectively.

\subsection{Contribution to Practice}

The results demonstrated China's constant efforts in innovation investment, environmental protection, energy conservation, and reduction of carbon emissions. Efficiency values of economically developed eastern China were always higher than the national level, while the less-developed central and western areas of China had lower efficiencies values in comparison to the national level. Sustainable innovation governance still needs to be valued, since innovation efficiency in China should be improved further, especially in the central and western areas. Regional coordinated development could be strengthened to narrow the regional differences. At the same time, different regions have their own advantages, including geographical and economic advantages. Each region should make full use of these unique characteristics to promote sustainable development.

Companies should not only pursue patent output and economic income, but should pay more and more attention to issues of energy consumption and environmental pollution. Clean energies could be implemented to alleviate excessive dependence on fossil fuels and meet growing energy demands. Environmentally friendly technologies may be used for firms' sustainable innovation gains. High pollution industries should be controlled, while new energy-saving technologies need to be improved. Moreover, the government should not blindly increase funding, but vigorously develop the technology market to promote more innovation outputs.

\subsection{Limitations}

Our research had its limitations. First of all, this research lacked broader considerations covering social, economic, and political sustainability, since environmental sustainability is the central issue in this study. Secondly, although the DEA method can deal with multi-output analysis, it cannot measure the influence of random errors on efficiency, which attributes the uncontrollable factors and 
statistical errors to inefficiency, and results in relatively low efficiency values. Thirdly, there was the limitation that the number of DMUs should be more than three times the number of indicators in the DEA method, we were able to use only three input indicators and four output indicators. Other indicators could also represent the undesirable outputs. Considering the data availability, we selected $\mathrm{SO}_{2}$ and $\mathrm{CO}_{2}$ emissions as the undesirable outputs. Fourthly, we only analyzed the influencing factors of sustainable innovation efficiency by regression model, but did not further study the mechanisms of these factors.

\subsection{Future Research}

Our research found significant differences in sustainable innovation efficiency at the provincial and regional levels. Since there are always huge gaps in economic and technological development between cities in one province, future research could consider applying this research approach at the city level which would better explain the regional differences. This is because the agglomerations of cities and industries could affect regional innovation greatly. Currently, many urban clusters and industrial belts are emerging within China. It is also meaningful for future research to focus on urban clusters and industrial belts. In addition, innovation research with undesirable outputs can be applied to the field of industrial innovation, focusing on the analysis of heavily polluting industries. Future research can analyze in detail the specific mechanisms of influencing factors of sustainable innovation efficiency, such as how government R\&D funding reduces the innovation efficiency, and how the technology market promotes innovation outputs. Technological innovation and environmental regulations are closely related to regional economic growth. The relation between environmental sustainability and economic growth is well worth studying. Future research can also be carried out from this perspective.

\section{Conclusions and Implications}

This study gave insight into regional sustainable innovation efficiency with undesirable outputs, and evaluated the efficiency from 2015 to 2016 through a super efficiency SBM model. This research took industrial waste and total energy consumption into consideration. The evaluation results indicated that 12 provinces in China have increased efficiency values from 2015 to 2016, with Beijing and Guangdong taking the two top spots. Meanwhile, it is noteworthy that the innovation efficiency among provinces was quite different. Innovation efficiency differed widely across regions. The eastern area still led the technological innovation and efficiency in China, in comparison to the central and western areas. Moreover, regional disparities between the three areas are subtly increasing.

Given the increasing differences in regional innovation efficiency across the whole country, the Chinese central government should pay special attention to regional disparities. More scientific and technological resources should be invested in the vast central and western areas. Based on our results, technology market maturity affected sustainable innovation efficiency significantly, while government funding had a negative impact on sustainable innovation efficiency. Industrial structure and environmental regulations showed no significant effect on sustainable innovation efficiency.

From the above conclusion, several policy implications are obtained. Firstly, policymakers should pay more attention to the overall development of the economy and the environment, instead of focusing only on economic development. The improvement of innovation efficiency requires good governance of sustainability measures and practices. Since pollution mitigation and energy conservation affect sustainable innovation efficiency greatly, it is urgent to increase sustainable technology investment in order to reduce energy consumption and industrial pollutant emissions. Secondly, the central government needs to address environmental issues from a long-term perspective, since local governments are more likely to pursue short-term benefits and ignore long-term environmental issues. Both command-and-control measures and market-based policy instruments should be employed to address the environmental problems caused by rapid, unsustainable development. Thirdly, it is unwise for the government to blindly increase investment in scientific and technological resources as before. On the contrary, it should apply more consideration to vigorously adopt strict governance 
measures in the technology market to promote innovation. Lastly, regional disparities should be taken into account. The government should strengthen cooperation in regional innovation governance to narrow the regional disparities. As China is a huge country with varying regional social-economic development levels, policymakers in each province could formulate targeted policies on energy saving and carbon emissions reduction in light of their provincial features. Specifically, the eastern provinces should enact policies to guide technological innovation. Central and western provinces should optimize the industrial structure, accelerate industrial upgrading, and reduce energy consumption and environmental pollution.

Author Contributions: Conceptualization, K.X., L.L., and Q.C.; Data curation, K.X.; Formal analysis, K.X. and L.L.; Funding acquisition, L.L. and Q.C.; Methodology, K.X.; Project administration, L.L. and Q.C.; Resources, L.L. and Q.C.; Supervision, L.L. and Q.C.; Validation, K.X., L.L., and Q.C.; Visualization, K.X. and L.L.; Writing original draft, K.X. and L.L.; Writing - review \& editing, L.L. and Q.C. All authors have read and agreed to the published version of the manuscript.

Funding: This research received no external funding.

Acknowledgments: The authors would like to thank the editor and anonymous reviewers for their insightful comments and suggestions.

Conflicts of Interest: The authors declare no conflict of interest.

\section{References}

1. Nill, J.; Kemp, R. Evolutionary approaches for sustainable innovation policies: From niche to paradigm? Res. Policy 2009, 38, 668-680. [CrossRef]

2. Yam, R.C.M.; Guan, J.C.; Pun, K.F.; Tang, E.P.Y. An audit of technological innovation capabilities in chinese firms: Some empirical findings in Beijing, China. Res. Policy 2004, 33, 1123-1140. [CrossRef]

3. Li, Z.; Li, J.; He, B. Does foreign direct investment enhance or inhibit regional innovation efficiency? Chin. Manag. Stud. 2018, 12, 35-55. [CrossRef]

4. Bai, J. On Regional Innovation Efficiency: Evidence from Panel Data of China's Different Provinces. Reg. Stud. 2013, 47, 773-788. [CrossRef]

5. Tian, X.; Wang, J. Research on Spatial Correlation in Regional Innovation Spillover in China Based on Patents. Sustainability 2018, 10, 3090. [CrossRef]

6. Chen, K.; Guan, J. Measuring the Efficiency of China's Regional Innovation Systems: Application of Network Data Envelopment Analysis (DEA). Reg. Stud. 2012, 46, 355-377. [CrossRef]

7. Feng, C.; Wang, M. The heterogeneity of China's pathways to economic growth, energy conservation and climate mitigation. J. Clean. Prod. 2019, 228, 594-605. [CrossRef]

8. Yu, Y.; Qian, T.; Du, L. Carbon productivity growth, technological innovation, and technology gap change of coal-fired power plants in China. Energy Policy 2017, 109, 479-487. [CrossRef]

9. Zhang, W.; Pan, X.; Yan, Y.; Pan, X. Convergence analysis of regional energy efficiency in china based on large-dimensional panel data model. J. Clean. Prod. 2017, 142, 801-808. [CrossRef]

10. Broekel, T. Collaboration Intensity and Regional Innovation Efficiency in Germany-A Conditional Efficiency Approach. Ind. Innov. 2012, 19, 155-179. [CrossRef]

11. Holley, C.; Lecavalier, E. Energy governance, energy security and environmental sustainability: A case study from Hong Kong. Energy Policy 2017, 108, 379-389. [CrossRef]

12. Salvioni, D.; Gennari, F.; Bosetti, L. Sustainability and Convergence: The Future of Corporate Governance Systems? Sustainability 2016, 8, 1203. [CrossRef]

13. Husted, B.W.; Sousa-Filho, J.M.D. The impact of sustainability governance, country stakeholder orientation, and country risk on environmental, social, and governance performance. J. Clean. Prod. 2017, 155, 93-102. [CrossRef]

14. Rajesh, R. Exploring the sustainability performances of firms using environmental, social, and governance scores. J. Clean. Prod. 2020, 247, 119600. [CrossRef]

15. Zhao, Z.-Q.; He, B.-J.; Li, L.-G.; Wang, H.-B.; Darko, A. Profile and concentric zonal analysis of relationships between land use/land cover and land surface temperature: Case study of Shenyang, China. Energy Build. 2017, 155, 282-295. [CrossRef] 
16. He, B.-J.; Zhao, D.-X.; Zhu, J.; Darko, A.; Gou, Z.-H. Promoting and implementing urban sustainability in China: An integration of sustainable initiatives at different urban scales. Habitat. Int. 2018, 82, 83-93. [CrossRef]

17. De Guimarães, J.C.F.; Severo, E.A.; Felix Júnior, L.A.; Da Costa, W.P.L.B.; Salmoria, F.T. Governance and quality of life in smart cities: Towards sustainable development goals. J. Clean. Prod. 2020, 253, 119926. [CrossRef]

18. Hussain, N.; Rigoni, U.; Orij, R.P. Corporate Governance and Sustainability Performance: Analysis of Triple Bottom Line Performance. J. Bus. Ethics 2016, 149, 411-432. [CrossRef]

19. Lombardi, R.; Cano-Rubio, M.; Trequattrini, R.; Fuentes-Lombardo, G. Exploratory evidence on anticorruption activities in the Spanish context: A sustainable governance approach. J. Clean. Prod. 2020, 249, 119424. [CrossRef]

20. Ioppolo, G.; Cucurachi, S.; Salomone, R.; Saija, G.; Shi, L. Sustainable Local Development and Environmental Governance: A Strategic Planning Experience. Sustainability 2016, 8, 180. [CrossRef]

21. Blendinger, G.; Michalski, G. Long-Term Competitiveness Based on Value Added Measures as Part of Highly Professionalized Corporate Governance Management of German Dax 30 Corporations. J. Compet. 2018, 10, 5-20. [CrossRef]

22. Mahmood, M.; Orazalin, N. Green governance and sustainability reporting in Kazakhstan's oil, gas, and mining sector: Evidence from a former USSR emerging economy. J. Clean. Prod. 2017, 164, 389-397. [CrossRef]

23. Schrobback, P.; Meath, C. Corporate sustainability governance: Insight from the Australian and New Zealand port industry. J. Clean. Prod. 2020, 255, 120280. [CrossRef]

24. Shin, J.; Kim, C.; Yang, H. The Effect of Sustainability as Innovation Objectives on Innovation Efficiency. Sustainability 2018, 10, 1966. [CrossRef]

25. Lupova-Henry, E.; Dotti, N.F. Governance of sustainable innovation: Moving beyond the hierarchy-marketnetwork trichotomy? A systematic literature review using the 'who-how-what' framework. J. Clean. Prod. 2019, 210, 738-748. [CrossRef]

26. Naciti, V. Corporate governance and board of directors: The effect of a board composition on firm sustainability performance. J. Clean. Prod. 2019, 237, 117727. [CrossRef]

27. Wang, W.; Yu, B.; Yan, X.; Yao, X.; Liu, Y. Estimation of innovation's green performance: A range-adjusted measure approach to assess the unified efficiency of China's manufacturing industry. J. Clean. Prod. 2017, 149, 919-924. [CrossRef]

28. Chen, C.; Han, J.; Fan, P. Measuring the Level of Industrial Green Development and Exploring Its Influencing Factors: Empirical Evidence from China's 30 Provinces. Sustainability 2016, 8, 153. [CrossRef]

29. Cooke, P. Regional innovation systems: Competitive regulation in the new Europe. Geoforum 1992, 23, 365-382. [CrossRef]

30. Cooke, P.; Boekholt, P.; Schall, N.; Schienstock, G. Regional innovation systems: Concepts, analysis and typology. In Proceedings of the EU-RESTPOR Conference Global Comparison of Regional RTD and Innovation Strategies for Development and Cohesion, Brussels, Belgium, 19 September 1996; pp. $19-21$.

31. Cooke, P.; Gomez Uranga, M.; Etxebarria, G. Regional innovation systems: Institutional and organisational dimensions. Res. Policy 1997, 26, 475-491. [CrossRef]

32. Baregheh, A.; Rowley, J.; Sambrook, S. Towards a multidisciplinary definition of innovation. Manag. Decis. 2009, 47, 1323-1339. [CrossRef]

33. Saunila, M.; Ukko, J.; Rantala, T. Sustainability as a driver of green innovation investment and exploitation. J. Clean. Prod. 2018, 179, 631-641. [CrossRef]

34. Hellström, T. Dimensions of environmentally sustainable innovation: The structure of eco-innovation concepts. Sustain. Dev. 2007, 15, 148-159. [CrossRef]

35. Yuan, B.; Xiang, Q. Environmental regulation, industrial innovation and green development of Chinese manufacturing: Based on an extended CDM model. J. Clean. Prod. 2018, 176, 895-908. [CrossRef]

36. Fernández Fernández, Y.; Fernández López, M.A.; Olmedillas Blanco, B. Innovation for sustainability: The impact of R\&D spending on $\mathrm{CO}_{2}$ emissions. J. Clean. Prod. 2018, 172, 3459-3467.

37. Ramanathan, R.; He, Q.; Black, A.; Ghobadian, A.; Gallear, D. Environmental regulations, innovation and firm performance: A revisit of the Porter hypothesis. J. Clean. Prod. 2017, 155, 79-92. [CrossRef] 
38. Hansen, E.G.; Grosse-Dunker, F.; Reichwald, R. Sustainability Innovation Cube-A Framework to Evaluate Sustainability-Oriented Innovations. Int. J. Innov. Manag. 2011, 13, 683-713. [CrossRef]

39. Liu, X.; Guo, P.; Guo, S. Assessing the eco-efficiency of a circular economy system in China's coal mining areas: Emergy and data envelopment analysis. J. Clean. Prod. 2019, 206, 1101-1109. [CrossRef]

40. Li, K.; Song, M. Green Development Performance in China: A Metafrontier Non-Radial Approach. Sustainability 2016, 8, 219. [CrossRef]

41. Wei, Y.-M.; Chen, H.; Chyong, C.K.; Kang, J.-N.; Liao, H.; Tang, B.-J. Economic dispatch savings in the coal-fired power sector: An empirical study of China. Energy Econ. 2018, 74, 330-342. [CrossRef]

42. Gu, W.; Zhao, X.; Yan, X.; Wang, C.; Li, Q. Energy technological progress, energy consumption, and $\mathrm{CO}_{2}$ emissions: Empirical evidence from China. J. Clean. Prod. 2019, 236, 117666. [CrossRef]

43. Farrell, M.J. The Measurement of Productive Efficiency. J. R. Stat. Soc. Ser. A 1957, 120, 253-290. [CrossRef]

44. Hall, B.H.; Griliches, Z.; Hausman, J.A. Patents and R and D: Is There a Lag? Int. Econ. Rev. 1986, $27,265$. [CrossRef]

45. Acs, Z.J.; Anselin, L.; Varga, A. Patents and innovation counts as measures of regional production of new knowledge. Res. Policy 2002, 31, 1069-1085. [CrossRef]

46. Chen, C.-M.; Delmas, M.A.; Lieberman, M.B. Production frontier methodologies and efficiency as a performance measure in strategic management research. Strateg. Manag. 2015, 36, 19-36. [CrossRef]

47. Lee, H.Y.; Park, Y.T. An international comparison of R\&D efficiency: DEA approach. Asian J. Technol. Innov. 2005, 13, 207-222.

48. Sharma, S.; Thomas, V.J. Inter-country R\&D efficiency analysis: An application of data envelopment analysis. Scientometrics 2008, 76, 483-501.

49. Guan, J.; Chen, K. Modeling macro-R\&D production frontier performance: An application to Chinese province-level R\&D. Scientometrics 2009, 82, 165-173.

50. Karadayi, M.A.; Ekinci, Y. Evaluating R\&D performance of EU countries using categorical DEA. Technol. Anal. Strateg. 2018, 31, 227-238.

51. Wang, X.; Wu, Q.; Majeed, S.; Sun, D. Fujian's Industrial Eco-Efficiency: Evaluation Based on SBM and the Empirical Analysis of lnfluencing Factors. Sustainability 2018, 10, 3333. [CrossRef]

52. He, B.; Wang, J.; Wang, J.; Wang, K. The Impact of Government Competition on Regional R\&D Efficiency: Does Legal Environment Matter in China's Innovation System? Sustainability 2018, 10, 4401.

53. Dai, X.; Wu, J.; Yan, L. A Spatial Evolutionary Study of Technological Innovation Talents' Sticky Wages and Technological Innovation Efficiency Based on the Perspective of Sustainable Development. Sustainability 2018, 10, 4201. [CrossRef]

54. Chen, K.; Kou, M.; Fu, X. Evaluation of multi-period regional R\&D efficiency: An application of dynamic DEA to China's regional R\&D systems. Omega 2018, 74, 103-114.

55. Anderson; Stejskal, Diffusion Efficiency of Innovation among EU Member States: A Data Envelopment Analysis. Economies 2019, 7, 34. [CrossRef]

56. Belgin, O. Analysing R\&D efficiency of Turkish regions using data envelopment analysis. Technol. Anal. Strateg. 2019, 31, 1341-1352.

57. Cao, S.; Feng, F.; Chen, W.; Zhou, C. Does market competition promote innovation efficiency in China's high-tech industries? Technol. Anal. Strateg. 2019, 32, 429-442. [CrossRef]

58. Hong, J.; Hong, S.; Wang, L.; Xu, Y.; Zhao, D. Government grants, private R\&D funding and innovation efficiency in transition economy. Technol. Anal. Strateg. 2015, 27, 1068-1096.

59. Hou, B.; Hong, J.; Wang, H.; Zhou, C. Academia-industry collaboration, government funding and innovation efficiency in Chinese industrial enterprises. Technol. Anal. Strateg. 2018, 31, 692-706. [CrossRef]

60. Qin, X.; Du, D. Measuring universities' R\&D performance in China's provinces: A multistage efficiency and effectiveness perspective. Technol. Anal. Strateg. 2018, 30, 1392-1408.

61. Yang, F.; Cheng, Y.; Yao, X. Influencing factors of energy technical innovation in China: Evidence from fossil energy and renewable energy. J. Clean. Prod. 2019, 232, 57-66. [CrossRef]

62. Wicki, S.; Hansen, E.G. Green technology innovation: Anatomy of exploration processes from a learning perspective. Bus. Strategy. Environ. 2019, 28, 970-988. [CrossRef] [PubMed]

63. Luo, Q.; Miao, C.; Sun, L.; Meng, X.; Duan, M. Efficiency evaluation of green technology innovation of China's strategic emerging industries: An empirical analysis based on Malmquist-data envelopment analysis index. J. Clean. Prod. 2019, 238, 117782. [CrossRef] 
64. Li, X. China's regional innovation capacity in transition: An empirical approach. Res. Policy 2009, 38, 338-357. [CrossRef]

65. Lin, S.; Sun, J.; Marinova, D.; Zhao, D. Evaluation of the green technology innovation efficiency of China's manufacturing industries: DEA window analysis with ideal window width. Technol. Anal. Strateg. 2018, 30, 1166-1181. [CrossRef]

66. Broekel, T.; Rogge, N.; Brenner, T. The innovation efficiency of German regions-A shared-input DEA approach. Rev. Reg. Res. 2017, 38, 77-109. [CrossRef]

67. Zhang, J.; Liu, Y.; Chang, Y.; Zhang, L. Industrial eco-efficiency in China: A provincial quantification using three-stage data envelopment analysis. J. Clean. Prod. 2017, 143, 238-249. [CrossRef]

68. Chakraborty, P.; Chatterjee, C. Does environmental regulation indirectly induce upstream innovation? New evidence from India. Res. Policy 2017, 46, 939-955. [CrossRef]

69. Ambec, S.; Cohen, M.A.; Elgie, S.; Lanoie, P. The Porter Hypothesis at 20: Can Environmental Regulation Enhance Innovation and Competitiveness? Rew. Environ. Econ. Policy 2013, 7, 2-22. [CrossRef]

70. Rennings, K.; Rammer, C. The Impact of Regulation-Driven Environmental Innovation on Innovation Success and Firm Performance. Ind. Innov. 2011, 18, 255-283. [CrossRef]

71. Sueyoshi, T.; Yuan, Y.; Goto, M. A literature study for DEA applied to energy and environment. Energy Econ. 2017, 62, 104-124. [CrossRef]

72. Emrouznejad, A.; Yang, G.-1. A survey and analysis of the first 40 years of scholarly literature in DEA: 1978-2016. Socioecon. Plann. Sci. 2018, 61, 4-8. [CrossRef]

73. Charnes, A.; Cooper, W.W.; Rhodes, E. Measuring the efficiency of decision making units. Eur. J. Oper. Res. 1978, 2, 429-444. [CrossRef]

74. Seiford, L.M.; Zhu, J. Modeling undesirable factors in efficiency evaluation. Eur. J. Oper. Res. 2002, 142, 16-20. [CrossRef]

75. Scheel, H. Undesirable outputs in efficiency valuations. Eur. J. Oper. Res. 2001, 132, 400-410. [CrossRef]

76. Seiford, L.M.; Zhu, J. A response to comments on modeling undesirable factors in efficiency evaluation. Eur. J. Oper. Res. 2005, 161, 579-581. [CrossRef]

77. Färe, R.; Grosskopf, S. Modeling undesirable factors in efficiency evaluation: Comment. Eur. J. Oper. Res. 2004, 157, 242-245. [CrossRef]

78. Tone, K. A slacks-based measure of super-efficiency in data envelopment analysis. Eur. J. Oper. Res. 2002, 143, 32-41. [CrossRef]

79. Yang, T.; Chen, W.; Zhou, K.; Ren, M. Regional energy efficiency evaluation in China: A super efficiency slack-based measure model with undesirable outputs. J. Clean. Prod. 2018, 198, 859-866. [CrossRef]

80. Guan, J.; Chen, K. Measuring the innovation production process: A cross-region empirical study of China's high-tech innovations. Technovation 2010, 30, 348-358. [CrossRef]

81. Liu, Z.; Chen, X.; Chu, J.; Zhu, Q. Industrial development environment and innovation efficiency of high-tech industry: Analysis based on the framework of innovation systems. Technol. Anal. Strateg. 2017, 30, 434-446. [CrossRef]

82. Chen, X.; Liu, Z.; Zhu, Q. Performance evaluation of China's high-tech innovation process: Analysis based on the innovation value chain. Technovation 2018, 74-75, 42-53. [CrossRef]

83. Wang, K.; Wei, Y.-M.; Zhang, X. A comparative analysis of China's regional energy and emission performance: Which is the better way to deal with undesirable outputs? Energy Policy 2012, 46, 574-584. [CrossRef]

84. Jiang, J.; Ye, B.; Xie, D.; Li, J.; Miao, L.; Yang, P. Sector decomposition of China's national economic carbon emissions and its policy implication for national ETS development. Renew. Sustain. Energy Rev. 2017, 75, 855-867. [CrossRef]

85. Zhang, Y.-J.; Peng, Y.-L.; Ma, C.-Q.; Shen, B. Can environmental innovation facilitate carbon emissions reduction? Evidence from China. Energy Policy 2017, 100, 18-28. [CrossRef]

86. Wang, K.; Wei, Y.-M.; Zhang, X. Energy and emissions efficiency patterns of Chinese regions: A multi-directional efficiency analysis. Appl. Energy 2013, 104, 105-116. [CrossRef]

87. Li, H.; Mu, H.; Zhang, M.; Gui, S. Analysis of regional difference on impact factors of China's energy-Related $\mathrm{CO}_{2}$ emissions. Energy 2012, 39, 319-326. [CrossRef]

88. McDonald, J. Using least squares and tobit in second stage DEA efficiency analyses. Eur. J. Oper. Res. 2009, 197, 792-798. [CrossRef] 
89. Nahra, T.A.; Mendez, D.; Alexander, J.A. Employing super-efficiency analysis as an alternative to DEA: An application in outpatient substance abuse treatment. Eur. J. Oper. Res. 2009, 196, 1097-1106. [CrossRef]

90. Bai, Y.; Song, S.; Jiao, J.; Yang, R. The impacts of government R\&D subsidies on green innovation: Evidence from Chinese energy-intensive firms. J. Clean. Prod. 2019, 233, 819-829.

91. Song, M.; Wang, S.; Sun, J. Environmental regulations, staff quality, green technology, R\&D efficiency, and profit in manufacturing. Technol. Forecast. Soc. 2018, 133, 1-14.

92. Wang, K.; Miao, N.-N.; Xue, K.-K. Does the technology background of the Party Committee Secretary affect firm's innovation efficiency? Evidence from listed state-owned enterprises in China. Technol. Anal. Strateg. 2019, 1-14. [CrossRef]

93. Howell, A. 'Indigenous' innovation with heterogeneous risk and new firm survival in a transitioning Chinese economy. Res. Policy 2015, 44, 1866-1876. [CrossRef]

(C) 2020 by the authors. Licensee MDPI, Basel, Switzerland. This article is an open access article distributed under the terms and conditions of the Creative Commons Attribution (CC BY) license (http://creativecommons.org/licenses/by/4.0/). 